\title{
SUSTAINABLE ARCHITECTURE IMPLEMENTATION OF VERNACULAR MOSQUE IN ACEH, INDONESIA
}

Received February 14th 2018 | Accepted April 12th 2018 | Available online December 15th 2018 |

DOI : http://dx. doi. org/10.18860/jia.v5i2.4812 |

Maysarah Bakri

UIN Ar-Raniry Banda Aceh

Banda Aceh, Indonesia

maysarah.bakri@gmail.com

\begin{abstract}
As one of the build environment's products, the existence of the building has a positive and negative contribution towards the surrounding. Along with the emerging of the environmental problems, the architecture sector offers the implementation of the sustainable architecture concept of each architecture object include the traditional and modern building. The application of this concept is the solution to solve the environment, social and economic problems which keep emerging. The aim of this concept is the improvement of the quality of those three aspects and the life of humanity itself. This research aims to find the implementation of sustainable architecture's theory on the vernacular mosque in Aceh. Masjid Tuha, Indrapuri, Aceh Besar is the object of the research. The method is descriptive qualitative which describes the result of observation. The observation is based on the research instrument. The result shows that Masjid Tuha, Indrapuri, Aceh Besar applies 20 of 34 sustainable architecture's indicators. The cultural conservation aspect implements the most numerous signs which mean the existence of the vernacular building itself is one concept of sustainable architecture. However, some other implementations need to be improved to get the best quality of execution.
\end{abstract}

\section{KEYWORDS:}

sustainable architecture; culture; vernacular mosque

\section{INTRODUCTION}

The impacts of environmental degradation have raised the awareness of human beings to live harmoniously with nature. One of it is implementing the sustainable concept in the architecture field. As one sector that closes to nature, it cannot be denied that in its process the architectural activities contribute to environmental degradation such as over-consumption of natural resources, waste or pollution. Therefore, the concept of sustainability should be applied in all architecture products include the mosque.

As the product of Islamic architecture, the mosque should implement Islamic values. One of the Islamic values related to the environment is the command to take care of the universe. A human has more responsibility to keep the prosperity of the world than any other living things (QS. Al-Baqarah (2): 30). In the architecture field, one of the responsible ways of dealing with this issue is by implementing the principles of sustainable architecture which is parallel with Islamic values [1].

Supporting this idea, the Indonesian government has instructed the implementation of the sustainable concept in any existing and new buildings [2]. The worship building included in buildings that are required to apply this concept [2]. The regulation shows the importance of the implementation of the sustainable idea in architecture products as the step to minimize the impacts of human activities toward the environment.

Generally, the sustainability concept is a threedimensional concept which consists of environment, social, and economy as the main pillars. Not only focus on one single component, but it also seeks equilibrium amongst those pillars and leads to the improvement of human quality of life [3].

The positive contributions from many sectors to those three pillars create the equilibrium. In modest understanding, the architecture product should consume less un-renewable resources for better environmental quality, should be effective and efficient, and should concern about the human which includes the socio-culture surrounding [4] [5] [6] [7].

However, there has been considerable discussion regarding the role of culture in the sustainable development framework. The debate raises three positions of culture which are the culture in sustainable development, the culture for sustainable development, and the culture as sustainable development [8] [9]. The first position places the culture as the fourth, thus 
as an additional element in the frame of sustainable development. In this case, the pillars are on the same level. Those pillars support the existence of sustainable development. The second position puts the culture in the middle of the economic-environmental-social triangle. By this condition, the culture acts as the center of sustainable development. It becomes the main consideration related to the issue of sustainable development. It cannot be denied since the culture shapes people's perspective towards economic, environmental, and social. It means in the second model; three other pillars also concern about the continuity of culture to achieve sustainability. It also says that some cultures can act as a ground for sustainable implementation. Some cultures in some region can be functioned as the base of sustainable development [10]. In the third position, the culture's position encompasses other pillars. In this particular case, the culture itself is sustainable since it contributes to the three pillars. Many kinds of culture are sustainable, such as vernacular buildings. Vernacular building is an example of an effective and efficient building [11]. Effective since it responses towards the geographical and social condition; efficient since it optimizes the resources nearby. For those reasons, the vernacular building is categorized as a sustainable building.

Sustainable architecture as one response to sustainable development issues brings up various principles. Kim and Rigdon stated that the economy of resources, life cycle design, and humane design are the principles of sustainable architecture [11], while Ardiani offers urban ecology, water management, waste, material, the strategy of energy, economy, communities, cultural conservation, and operational management as the indicator of sustainable architecture [12]. Guy and Farmer suggest that ecotechnic, eco-aesthetic, eco-cultural, eco-centric, ecomedical and eco-social as the logic of sustainable architecture [13]. Meanwhile, Abioso categorizes the criteria of sustainable architecture building into several sections which are the site and the building, the procurement strategy, the policy, the roles of architect, the material, the consumption of energy, and the use of other resources [14]; each section has several detailed criteria of sustainable implementation which starts from the site into the interior of the building.

Despite its different labeling, the universal principles are related to water management, energy efficiency, waste and materials, ecology, and socio culture. In summary, the sustainable building applies the principles such as treating the grey water, optimizing the renewable energy resources, using the concept of reuse-reduce-recycle, providing ecosystem, conserving the culture, and ensuring the quality of life of a human. Since the architectural product consumes many resources, the sustainable building should optimize the local potencies; the labor, the material, the wind, the rainwater, the sun, the socio-culture on the existing site. By applying those principles, the building contributes less adverse impact on the environment, increases the economic values and strengthen the social cohesion in the society which leads to the achievement of sustainable development.

Furthermore, there are many researchers have researched the sustainability value attached on vernacular architecture. Those researchers had proved that vernacular architecture meets the requirements to be categorized as a sustainable building [4] [10] [11] [15]. Meanwhile, related to the concept of sustainability in the mosques, some researches had been done by Adi and Puspitasari, and Imriyanti [4] [7]. However, none of those researches focus on the vernacular mosque. Most of the previous researches used the modern mosque as the case study.

In Aceh itself, the existence of the mosque holds an essential position in the society. Besides as the house of worship, the mosque also functions as the social and education space. Its massive role as the activity center of Muslim communities can affect the social economy condition surrounding and unite the communities [4]. For that reason, the design of the mosque should implement the concept of sustainability because it will affect the communities. The mosque can be one pilot project of sustainable building in the society. Considering the number of it is in Aceh, the implementation of the sustainable concept in the mosque can significantly contribute to the implementation of sustainable development.

Masjid Tuha, Indrapuri is one of the well-known vernacular mosques in Aceh. In the past, this mosque functioned as the temple which used by Lamuri Kingdom [16]. After the king became a Muslim, the temple's function was converted as the mosque corresponding his people's idea [16]. The remains of Hindu culture can still be seen in some parts of this mosque, some of it is the steps and the terraced roof [17]. Nowadays, Masjid Tuha, Indrapuri is one of cultural heritage in Aceh. Vernacular buildings are well known for its high adaptability. It can be seen from the design that is in harmony with the climate and nature [18] [19] [20] [21]. From that point of view, as the hypothesis, the existence of Masjid Tuha, Indrapuri as the vernacular mosque has fulfilled one aspect of the sustainable concept which is a positive contribution to the environment. However, the hypothesis has to be proved through further research.

The first aim of this research is to find the implementation of sustainable architecture in Masjid Tuha, Indrapuri, Aceh Besar as one of the vernacular mosques in Aceh. Despite its old age, this mosque still functions until now. Furthermore, the research also tries to find the building contribution towards the sustainable development. Last but not least, the objective of the study is to find the role of culture in this case study related to sustainable development.

\section{METHODS}

The research method is descriptive qualitative. The use of this method combination because both of it can describe in detail and accurate in many cases [22]. 
In another word, the use of this method is suitable to study examples research.

The source of data is collected through observation in the field and interview. It is also supported by related literature review. The instrument for the observation uses the application list of the principles of sustainable architecture stated by Ardiani which can be seen in table 1.

Table 1. The Principles and the Application of Sustainable Architecture [12]

\begin{tabular}{|c|c|}
\hline The Principles & The Application \\
\hline Urban Ecology & $\begin{array}{l}\text { Providing vegetation on the site or verti- } \\
\text { cal garden } \\
\text { Offering a roof garden }\end{array}$ \\
\hline $\begin{array}{l}\text { Strategy of } \\
\text { Energy }\end{array}$ & $\begin{array}{l}\text { Using a passive cooling system } \\
\text { Using local construction material } \\
\text { Using sensory technology }\end{array}$ \\
\hline Water & $\begin{array}{l}\text { Using the roof as water receiver } \\
\text { Water conservation } \\
\text { Reusing rainwater for kitchen purpose } \\
\text { and shower } \\
\text { Reusing grey water } \\
\text { Treating and reusing black water to be } \\
\text { fertilizer } \\
\text { Collecting and managing the rain } \\
\text { Treating the grey water to be purified } \\
\text { water }\end{array}$ \\
\hline Waste & $\begin{array}{l}\text { Liquid and solid waste treatment to be } \\
\text { energy resource } \\
\text { Using recycled material }\end{array}$ \\
\hline Material & $\begin{array}{l}\text { Reuse } \\
\text { Recycle } \\
\text { Using fast produced material such as } \\
\text { bamboo } \\
\text { Using local material } \\
\text { Using the prefabrication construction } \\
\text { system with modular systems } \\
\text { Re-utilization }\end{array}$ \\
\hline Communities & $\begin{array}{l}\text { Respect and care towards society } \\
\text { Strengthen caring communities } \\
\text { Eco-Urbanism }\end{array}$ \\
\hline $\begin{array}{l}\text { The strategy } \\
\text { of the econo- } \\
\text { my }\end{array}$ & Providing job vacancy \\
\hline $\begin{array}{l}\text { Cultural con- } \\
\text { servation }\end{array}$ & $\begin{array}{l}\text { Revitalization of traditional building } \\
\text { Preserving the way of the build which } \\
\text { exist in the conventional building } \\
\text { Using local labor } \\
\text { Preserving culture }\end{array}$ \\
\hline Operational & Integrated management of wastewater \\
\hline
\end{tabular}

\section{RESULTAND DISC USSION}

RESULT: THE IMPLEMENTATION OF SUSTAINABIE ARCHITECTURE

Based on the observation, Masjid Tuha, Indrapuri implements 20 of 34 sustainable architecture principles. From the perspective of urban ecology, Masjid Tuha, Indrapuri has open green space. At the first step, the open green space reached $80 \%$ of the total area and planted with productive vegetation. Moreover, at the second step, there is a $10 \%$ open green space which planted with grasses. While at the third step, the percentage of open green space is $20 \%$ in the form of a passive garden.

Meanwhile, from the aspect of the strategy of energy, this mosque uses cross ventilation as one of the passive cooling systems. Additionally, there is the fan in the building. The opening around the mosque allows the circulation of the air inside the building. Unfortunately, some openings have been covered by the whiteboards on the north side of the building which blocks the air circulation, and some ventilation at the upper side has covered by plastic. Consequently, it reduces the quality of air circulation into the building.

Furthermore, the building uses wood, river rocks, mountain rocks and the clay as the material. Those materials are the local material. The wood is from the nearest forest while the river rocks come from the river on the west side of the mosque. The use of the local material is consistent with the concept of sustainable architecture because it reduces the carbon footprint. For the lighting, the building maximizes the natural light which comes into the building from the number of openings. Masjid Tuha, Indrapuri uses some of the renewable energy resources such as the sunlight, the rainwater, and the wind. Therefore, the implementation has saved the use of fossil energy although the use of it does not provide optimal yet.

Moreover, this mosque has a rainwater reservoir. The rainwater flows through pipes around the roof. The water in the tank then flows to another reservoir which used by the user for washing feet. Before the mosque has the ablution area, the pilgrims use the rainwater in the pool for ablution activity. Although it uses a simple technique, limited utilization and has not been treated optimally, this building has done one of water conservation steps. Nevertheless, the reservoir does not collect all of the rainwater. At some points, the rain is flawed to the pavement near the building.

From the perspective of waste and material, this mosque uses some recycled materials. The construction of the roof and column uses the wood which can be recycled later. Furthermore, Masjid Tuha, Indrapuri has applied an adaptive reuse concept. This concept means converting the function of building [12]. The purpose of the building has transformed from the temple to be the mosque in the period of Lamuri Kingdom. The adaptive reuse concept is one wise step which relevant to the sustainable architecture concept rather than abandoning the building or destroying the previous building.

The existence of the building also improves the quality of life of the society around the mosque. Some social activities take place in this place beside congregation prayers. The citizens still do discussion in and around the mosque. The recitation still happens in this building. Also, the mosque also contributes to the economic sector by providing jobs for the people. For instance, the mosque needs the cleaning service for maintaining the building. For that reason, the 
management of the mosque offers the job for the people. Thus, the worker gets income from the job. It also happens with the recitation teacher. Mostly, the workers come from the neighborhood. Although on a small scale, it means that the existence of the mosque increases the economy aspect of society.

Furthermore, the building applies the conservation of culture. It includes the revitalization of vernacular architecture, preserving the way of the build which exists in the vernacular building, using local labor and preserving the culture. The building of the mosque is a heritage which categorized as a vernacular building. As it still functions, the management of the mosque provides the facility for a better quality of the building. The improvement of building's quality means the revitalization of the building.

Moreover, the building still uses the traditional construction which is the stake system. It can be seen on the roof structure and the columns. Meanwhile, the labor is the local labor around the site. Consequently, it increases socio-economic condition surround the location of the mosque.

\section{DISCUSSION: THE ROLE OF CULTURE IN IMPLEMENTING THE \\ SUSTAINABLE ARCHITECTURE}

The score of the implementation of sustainable architecture in Masjid Tuha, Indrapuri can be seen in table 2. The instrument is based on Ardiani [12]. The higher score means the quality of implementation is excellent. While the less score implies the quality of the application is weak.

The most exciting finding is the implementation of sustainable architecture from the perspective of cultural conservation. From the table above, it can be seen that compared to other aspects, this mosque implements good quality of culture conservation aspect. It means that as the product of vernacular architecture, Masjid Tuha, Indrapuri, Aceh Besar has the values of sustainability from the perspective of culture. The notion of adaptive reuse plays an essential role in culture conservation. As it is converted to the mosque, the building still functions until now based on the social needs which unintentionally preserves the vernacular building and its values within.

Also, the building also applies other principles, even though the scale of the implementation varies and contributes to the improvement of economic, social and environment's quality. The contribution to the economic sector is by providing jobs, consequently, increasing the income of a family's worker. Moreover, the positive impact of the social area is improving the social cohesion which leads to the improvement of the quality of life. Meanwhile, the contribution to the environment is a less detrimental effect because the building optimizes the natural resources and consumes less energy. Thus, it is environmentally friendly. Therefore, it can be said that Masjid Tuha, Indrapuri is a sustainable building. The finding is consistent with other research which states that vernacular architecture is a sustainable building. Consequently, it strengthens the notion of preserving the mosque. Additionally, it is a heritage building.
Table 2. The Implementation of Sustainable Architecture in Masjid Tuha, Indrapuri, Aceh Besar

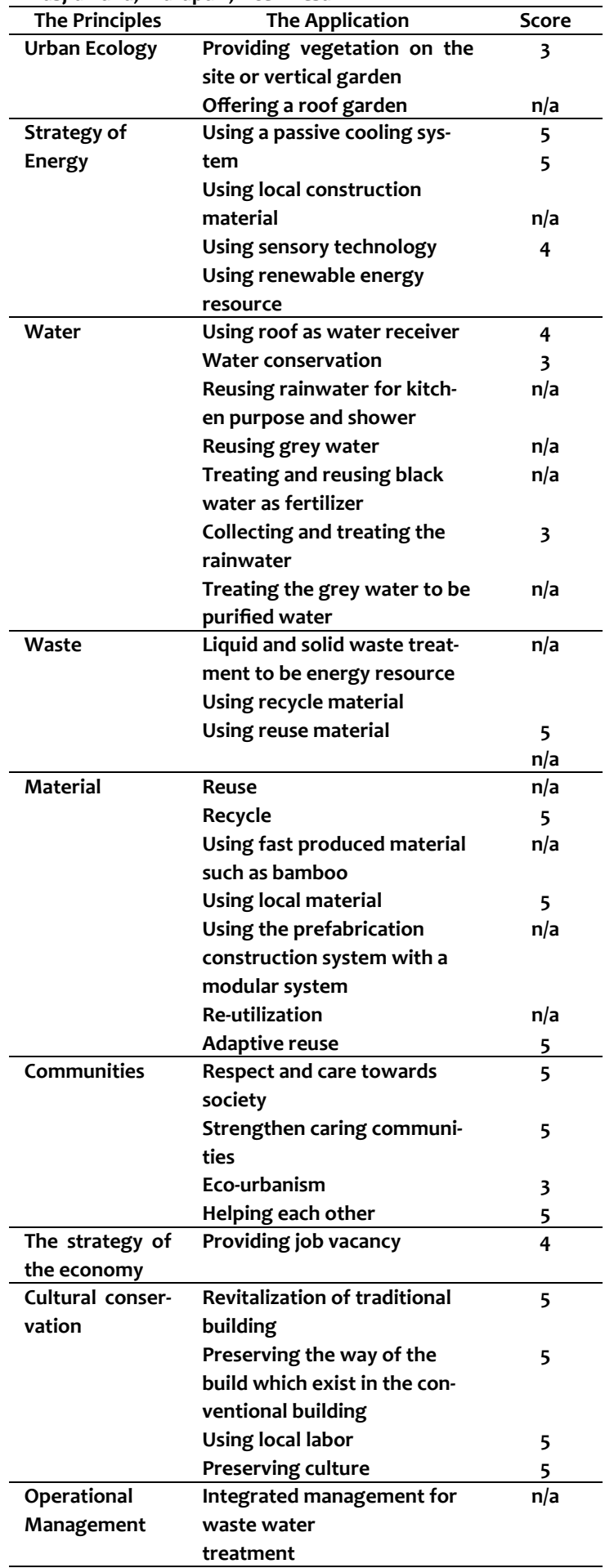

To ensure its continuity, the contemporary mosques can adapt some values of Masjid Tuha, Indrapuri especially the sustainable and cultural values; the physical and unphysical. It can be done by replication, critical or interpretive approach [15]. The replication approach is limited to constructing and imitate the same form of the vernacular building; the analytical method is adjusting the vernacular architecture to the 
current need, and interpretive approach is involving the concept of development on the vernacular building to meet the qualification of modern lifestyle [15]. The Masjid Tuha, Indrapuri itself is an example of the building which applies critical approach. Consequently, it still exists and functions until now.

Moreover, in this case, study, the culture holds a vital role in term of sustainable development. The finding shows that the culture fits with the third position which is culture as sustainable development. The environment, social and economic aspect get benefits from the existence of Masjid Tuha, Indrapuri and it embodies many cultural values, also. Thus, Masjid Tuha, Indrapuri as the product of culture is sustainable.

\section{CONCLUSION}

Taking everything into consideration, it can be concluded that Masjid Tuha, Indrapuri, Aceh Besar implements the sustainable architecture concept from the perspective of urban ecology, the strategy of energy, water, material, waste, communities, cultural conservation, and strategy of the economy. Furthermore, the cultural conservation aspect contributes significantly to the implementation of the sustainability concept. This building also plays an important role in its contribution to the economic, social, and environmental aspect. In this case study, the part of the culture is "culture as sustainable development" which demonstrates that Masjid Tuha, Indrapuri as a product of culture is a sustainable building.

The existence of Masjid Tuha, Indrapuri, Aceh Besar had shown that the vernacular architecture could be preserved. Additionally, maintaining the vernacular building is one implementation of sustainable architecture itself. Once it is conserved, there are also the values of sustainable architecture within. Therefore, there is a need to preserve the vernacular building in some kind of functions.

The research also shows that as a mosque, the building contributes to the improvement of human quality of life. Additionally, it also involves problemsolving towards global issues. So, the sustainable architecture's concept can be applied in other mosques as its contribution spread widely in society. As this research focuses on the physical aspect of cultural conservation, further research should be done to gain information about the unphysical values of the vernacular building which consistent with the concept of sustainable architecture.

\section{ACKNOWEDGMENTS}

This research was fully funded by DIPA UIN ArRaniry Banda Aceh 2017.

\section{REFERENCES}

[1] M. Bakri, "Sustainable Architecture through Islamic Perspective," in Conference Proceeding ARICIS I, 2016, pp. 491-499.
[2] K. P. U. dan P. Rakyat, Peraturan Menteri Pekerjaan Umum dan Perumahan Rakyat RI tentang Bangunan Gedung Hijau. Republik Indonesia, 2015.

[3] W. C. on E. and Development, Report of World Commission on Environment and Development: Our Common Future. 1987.

[4] Adi and Puspitasari, "Mosque as A Model of Learning Principles of Sustainable Architecture," J. Islam. Archit., vol. 4, no. 1, pp. 33-36, 2016.

[5] N. Utaberta, N. Asif, and H. Z, "EVALUATING POSSIBLE INNOVATIVE AND SUSTAINABLE APPROACH OF MOSQUE IN CONTEMPORARY WORLD," J. Des. + Built, vol. 9, pp. 56-61, 2016.

[6] A. Sedayu, "The priority of maintaining the reliability of sustainable construction at the Ampel Mosque Surabaya," in The 4th International Conference on Rehabilitation and Maintenance in Civil Engineering (ICRMCE 2018), 2018, pp. 1-15.

[7] Imriyanti, “Mosque Architecture as a Sustainable Building in Urban (Case Study: Al Markas Al Islamic Mosque Makassar)," J. Islam. Archit., vol. 2, no. 4, pp. 161-170, 2013.

[8] K. Soini, E. Battaglini, I. Birkeland, N. Duxburry, G. Fairclough, L. Horlings, and J. Dessein, "Culture in, for and as sustainable development," in the COST Action IS1007 Investigating Cultural Sustainability, 2015, pp. 20-34.

[9] Y. Rezapour, A. Jabbarieh, F. Behfar, A. Azami, and A. Shamsalghorayi, "Cultural Aspects Analyses in Sustainable Architecture," Int. J. Struct. Constr. Eng., vol. 6, no. 7, pp. 551-553, 2012.

[10] M. Bakri, "The Role of Culture in Implementing the Concept of Sustainability," in IOP Conf. Ser.: Earth Environ. Sci. 126 012137, 2018, pp. 1-8.

[11] N. E. Karabag and N. Fellahi, "Learning from Casbah of Algiers for more Sustainable Environment," Energy Procedia, vol. 133, pp. 95-108, 2017.

[12] Y. Ardiani, Arsitektur Berkelanjutan. Jakarta: Erlangga, 2017.

[13] S. Guy and G. Farmer, "Reinterpreting Sustainable Architecture: The Place of Technology," J. Archit. Educ., vol. 54, no. 3, pp. 140-148, 2001. 
[14] W. S. Abioso, "Sumbangan Arsitektur Sebagai Antisipasi terhadap Fenomena Energi Global," in Seminar Teknoinsentif, 2006.

[15] E. Hosseini, G. Mursib, R. Nafida, and B. Shahedi, "Design Values in Traditional Architecture: Malay House," in 6th International Seminar on Vernacular Settlements, Contemporary Vernaculars: Places, Processes, and Manifestations, 2012.

[16] A. B. Zein, Masjid-Masjid Bersejarah di Indonesia. Jakarta: Gema Insani Press, 1999.

[17] D. Annisa, "Pengaruh Arsitektur Hindu pada Masjid Tuha Indrapuri," in Prosiding Seminar Heritage IPLBI, 2017, pp. B317-320.

[18] J. McMinn and M. Polo, "Sustainable Architecture as a Cultural Project," 2005 World Sustain. Build. Conf., vol. 2005, no. September, pp. 4537 $-4544,2005$.
[19] S. Kültür, "Role of Culture in Sustainable Architecture," Arch. Transl. through Silk Road 2nd Int. Conf., pp. 262-267, 2012.

[20] J. M. Previtali and Z. Zhai, "A taxonomy of vernacular architecture: An addendum to 'ancient vernacular architecture: Characteristics categorization and energy performance evaluation' (Zhai and Previtali, 2010)," Energy Build., vol. 110, pp. 71-78, 2016.

[21] Z. (John) Zhai and J. M. Previtali, “Ancient vernacular architecture: characteristics categorization and energy performance evaluation," Energy Build., vol. 42, no. 3, pp. 357-365, 2010.

[22] W. L. Neuman, Metodelogi Penelitian Sosial: Pendekatan Kualitatif dan Kuantitatif. Jakarta: PT. Indeks, 2016. 